\title{
Some Statistical Characteristic of Malaysian Wind Direction Recorded at Maximum Wind Speed: 1999-2008
}

(Sebahagian Ciri Statistik Arah Angin Malaysia yang Direkodkan pada Kelajuan Angin Maksimum: 1999-2008)

\author{
S.Z. SATARI*, Y.Z.ZUBAIRI, A.G. HUSSIN \& S.F. HASSAN
}

\begin{abstract}
The statistical characteristics of wind direction that was recorded at maximum wind speed in Peninsular Malaysia for two monsoons from 1999 to 2008 for seven stations were analyzed in this study. Modeled by von Mises distribution, the change in parameters values namely mean direction and concentration parameter was measured. Statistical summary, graphical representations, Watson-William Test and linear-circular correlation are used in the analysis. It is found that there is a significant change in the mean direction of wind over the period of ten years for most stations in Peninsular Malaysia. However, there is a weak relationship between wind direction and wind speed. This study suggested the presence of prominent direction of wind that blows in Peninsular Malaysia by monsoon. This finding may provide useful information on giving a better understanding of the behavior of the wind in Peninsular Malaysia and the potential use of wind as an alternative source of energy.
\end{abstract}

Keywords: Circular statistics; climate; von Mises distribution; wind direction; wind speed

ABSTRAK

Ciri statistik arah angin yang dicatatkan pada kelajuan angin maksimum bagi tujuh stesen di Semenanjung Malaysia untuk dua monsun dari tahun 1999 hingga 2008 telah dianalisis dalam kajian ini. Arah angin ini dimodelkan oleh taburan von Mises dan perubahan dalam nilai-nilai parameternya iaitu min berarah serta parameter menumpu telah diukur.Ringkasan statistik, perwakilan grafik, ujian Watson-William dan korelasi linear membulat turut digunakan dalam analisis ini. Didapati bahawa terdapat perubahan ketara dalam min hala tuju angin sepanjang tempoh sepuluh tahun bagi kebanyakan stesen di Semenanjung Malaysia. Walau bagaimanapun, terdapat hubungan yang lemah antara arah angin dan kelajuan angin. Kajian ini mencadangkan terdapat kehadiran arah utama angin yang bertiup di Semenanjung Malaysia untuk setiap monsun. Penemuan ini boleh memberikan maklumat yang berguna serta pemahaman yang lebih baik terhadap tingkah laku angin di Semenanjung Malaysia dan potensi penggunaan angin sebagai sumber tenaga alternatif.

Kata kunci: Arah angin; iklim; kelajuan angin; statistik berarah; taburan von Mises

\section{INTRODUCTION}

The climate in the Peninsular of Malaysia can be described by humid tropical temperature with little variation throughout the year. It is situated between $1^{\circ} \mathrm{N}$ and $7^{\circ} \mathrm{N}$ latitude. However, other meteorological conditions such as wind and rainfall are very much dominated by the monsoon season. Malaysia experiences two monsoon seasons namely the southwest monsoon (June to September) and northeast monsoon (November to March) and two intermonsoon seasons (October and April to May).

Although Peninsular Malaysia does not have extreme weather conditions, it has suffered a fair share of turbulent (catastrophic) meteorological condition over the years. In June 2012 and August 2005, the haze in Malaysia is worsened by wind that brought in high pollutants from forest fires in Sumatera across the Straits of Malacca into the Peninsular Malaysia (Bernama 2012; Mahmud \& Ab Liah 2010; The Star 2005). Severe flash floods in September 2008 experienced by the northern region of the peninsular namely the states of Kedah and Northern Perak were due to heavy rain (Bernama 2008). In December 2006, the southern state of peninsular, Johor, suffered massive flood as a result of the typhoon Utor caused by tropical depression and severe tropical storm (Muhammad Barzani et al. 2010; Nur Aishah et al. 2012; The Star 2006). In 1997-1998, an unusually severe drought in the states of Kedah, Penang and Selangor was associated with the El Nino draught (Bernama 1998).

The climate change in the Peninsular Malaysia is monitored by the Malaysian Meteorological Departments which records daily temperature, rainfall, wind speed, wind direction, weather, wave height, earthquake and tsunami warning and satellite images. In 2009, a report on climate change scenarios for Malaysia from 2001 to 2099 was published. However it was reported that the climate models may not be totally successful to simulate severe future extreme events (Malaysian Meteorological Service Departments 2009). Fredolin et al. (2012) gave an overview of the current scientific knowledge of climate change over Malaysia and addressed that the knowledge 
gaps remain large with regards to extreme events such as flood and drought.

Past researchers show that there is a relationship between the wind direction with temperature, rainfall, wind speeds, and wave direction (Bowers et al. 2000; Brunsdon \& Charlton 2006; Jammaladaka \& Lund 2006). In Malaysia, the monsoon seasons influence the trend of wind speed (Razali et al. 2010). Kamisan et al. (2011, 2010) stated that, the monsoon based wind direction data fits well with the von Mises distribution as compared to the annual data set. In addition, studies on the potential future wind energy in Malaysia can be found in Chiang et al. (2003), Islam et al. (2011), Masseran et al. (2012a), Masseran et al. (2012b), Tiang and Ishak (2012) and Zaharim et al. (2009). Wind energy is related to the third power of the wind speed. Razali et al. (2010) stated that the power of wind that generated by a wind turbine is more efficient when the wind speed is fresh $(8.5-10.99 \mathrm{~m} / \mathrm{s})$ or strong (11-13.99 m/s).

Not many of these studies, however, consider both wind speed and direction. The analysis of wind speed and direction, however, is not straight forward. This is because wind speed is linear in nature but wind direction is a circular variable which is measured in degrees $(0,2 \pi)$ or radian $\left(0^{\circ}\right.$, $\left.360^{\circ}\right)$. In view of the wrap around nature of the data, the measure of central location and spread of circular data are different from the linear data. The von Mises distribution is the most common probability distribution of a circular random variable and the concentration of a circular data set is measured using the mean resultant length. A high concentration, which is more than five, indicates a tightly grouped distribution while low concentration corresponds to a distribution with much spread (Bowers et al. 2000).
Wind direction data with high value of concentration parameter suggest that the data is close to each other and may be an indicator of the prominent directions of wind. The aim of the study was to obtain statistical summaries of the wind direction recorded at maximum wind speed according to two monsoons over a period of ten years in Peninsular Malaysia. Our objective includes measuring the relationship between the wind speed and direction, if any. This kind of work has not been seen before and not available in any literatures.

\section{SOURCE OF DATA}

The data used in the study are daily wind direction data (in radian) recorded at maximum wind speed (in $\mathrm{m} / \mathrm{s}$ ) for seven stations, during the two monsoon seasons. These data were collected at altitude from 2.8 to $40.1 \mathrm{~m}$ from 1999 to 2008. For the west coast, the stations are located in Alor Setar, Bayan Lepas, Ipoh, KLIA and Subang, meanwhile for the east coast the stations are located in Kuala Terengganu and Kuantan (Figure 1). A total 153 data were obtained for the annual southwest monsoon, while 151 data were obtained for the annual northeast monsoon for all stations. All the data are obtained from the Malaysian Meteorology Service Department.

\section{METHODS}

\section{THE VON MISES DISTRIBUTION}

The von Mises distribution was first introduced by an Austrian Mathematician Richard Edler von Mises in 1918 and is denoted by $M\left(\mu_{0}, \kappa\right)$ with the probability density

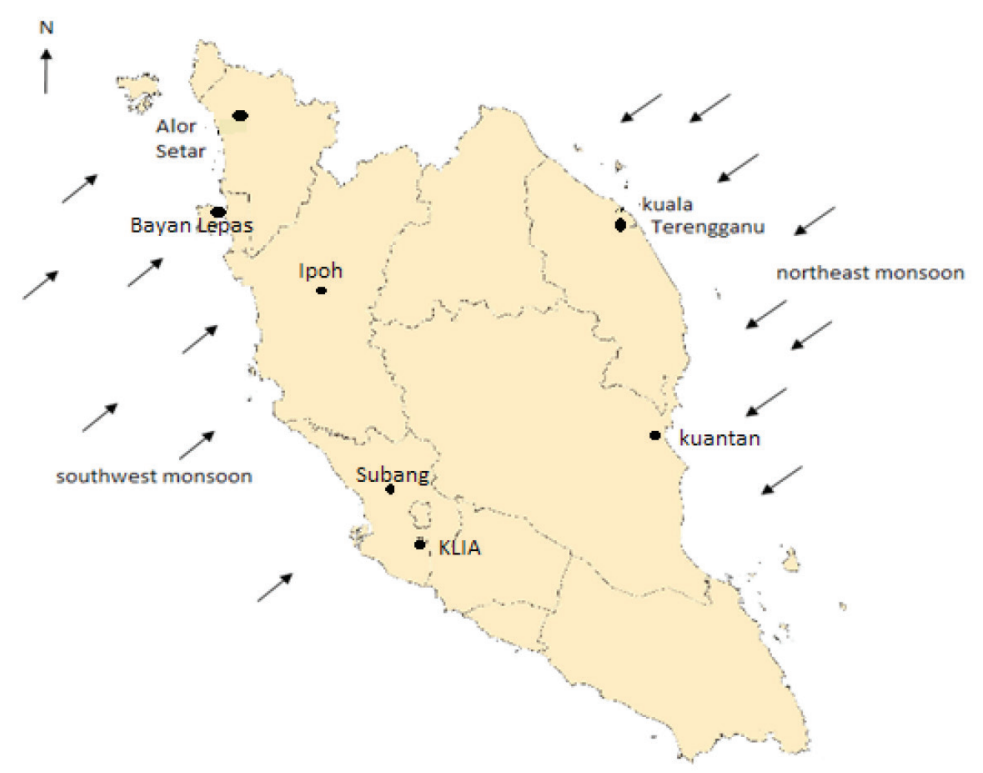

FIGURE 1. Locations of daily wind direction data that recorded at maximum wind speed from 1999 to 2008 
function (pdf) $f(\theta ; \mu, \kappa)=\frac{1}{2 \pi I_{0}(\kappa)} e^{\kappa \cos (\theta-\mu)}, 0 \leq \theta<2 \pi$, where $0 \leq \mu<2 \pi$ and $\kappa \geq 0$. The parameters $\mu$ is the mean direction and $\kappa$ is the concentration parameter. $I_{0}(\kappa)$ is the modified Bessel function of the first kind and order zero, which can be defined as $I_{0}(\kappa)=\frac{1}{2 \pi} \int_{0}^{2 \pi} e^{\kappa \cos \theta} d \theta=\sum_{r=0}^{\infty} \frac{1}{(r !)^{2}}\left(\frac{\kappa}{2}\right)^{2 r}$. Figure 2 shows von Mises densities for $\mu=0^{\circ}$ and different value of $\kappa$. Hence, the larger the value of $\kappa$, the greater the clustering around the mode, or the higher concentration towards the population mean direction $\mu$.

In particular, the mean resultant length $\rho$ is $A(\kappa)$ defined as:

$$
A(\kappa)=\frac{I_{1}(\kappa)}{I_{0}(K)} .
$$

The mean resultant length is also called the measure of concentration of data set. It describes how concentrated the data is towards the center (Jammaladaka \& SenGupta 2001; Mardia \& Jupp 2000). Thus, since $A(\kappa)=\rho$ and let $\theta_{1}, \theta_{1}, \ldots, \theta_{n}$ be a set of observations from $M\left(\mu_{0}, \kappa\right)$ then the maximum likelihood estimate $\hat{\kappa}$ of $\kappa$ is the solution of $A(\hat{\kappa})=\bar{R}=\sqrt{\bar{C}^{2}+\bar{S}^{2}}$, where $\bar{C}=\frac{1}{n} \sum_{j=1}^{n} \cos \theta_{j}$ and $\bar{S}=\frac{1}{n} \sum_{j=1}^{n} \cos \theta_{j}$.

Therefore, $\hat{\kappa}=A^{-1}(\bar{R}), 0 \leq \bar{R}<1$. Note that, the mean direction is given by:

$$
\mu= \begin{cases}\tan ^{-1}\left(\frac{\bar{S}}{\bar{C}}\right) & \text { if } \bar{C}>0, \bar{S} \geq 0, \\ \pi / 2 & \text { if } \bar{C}=0, \bar{S}>0, \\ \tan ^{-1}\left(\frac{\bar{S}}{\bar{C}}\right)+\pi & \text { if } \bar{C}<0, \\ \tan ^{-1}\left(\frac{\bar{S}}{\bar{C}}\right)+2 \pi & \text { if } \bar{C} \geq 0, \bar{S}<0, \\ \text { undefined } & \text { if } \bar{C}=0, \bar{S}=0 .\end{cases}
$$

Approximate solutions of concentration parameter, $\hat{\kappa}$ can be obtained by inverting the power series expansion of $A(\kappa)$ for small and large $\kappa$ separately. Works on obtaining the solution can be seen as early as 1953 (Amos 1974; Batshelet 1981; Best \& Fisher 1981; Dobson 1978; Gumbel et al. 1953; Hassan et al. 2012; Mardia 1972; Mardia \& Zemroch 1975a, 1975b). In this study, we used latest method of approximation as proposed by Hassan et al. (2012) to estimate the concentration parameter. The approximation of $\kappa$ was obtained by solving the piecewise polynomial functions involving the ratio of modified Bessel functions that is suitable for all values of $\kappa$. The approximation is given by:

$$
\hat{\kappa}= \begin{cases}A_{s}^{-1}(t) & t<0.6137 \\ A_{l}^{-1}(t) & t \geq 0.6137,\end{cases}
$$

where $t=A(\kappa), A_{s}(\kappa)=\frac{\kappa}{2}-\frac{\kappa^{3}}{16}+\frac{\kappa^{5}}{96}$ and $A_{l}(\kappa)=1-$ $\frac{1}{2 \kappa}-\frac{1}{8 \kappa^{2}}+\frac{1}{8 \kappa^{3}}$. Then for $t<0.6137, \kappa^{5}-6 \kappa^{3}+48 \kappa-96 t$ $=0$ and for $t \geq 0.6137,(8 t-8) \kappa^{3}+4 \kappa^{2}+\kappa+1=0$ These polynomial equations can be solved using polyroot function that is available in SPlus statistical package.

\section{StatisticAl TESTS ON Wind DiRECTION DATA}

Two statistical tests are used in the study namely WatsonWilliam Test (Mardia \& Jupp 2000) and linear-circular correlation measure. The software used in the analysis is Oriana as it provides useful features in the analysis of circular data.

\section{MULTI-SAMPLE WATSON-WILLIAM TEST}

The Watson-William Test is used to test the hypothesis that the mean directions of wind over ten year period are equal. Assume that $\kappa_{1}=\ldots=\kappa_{q}$ where the common concentration $\kappa$ is unknown, and let the null hypothesis

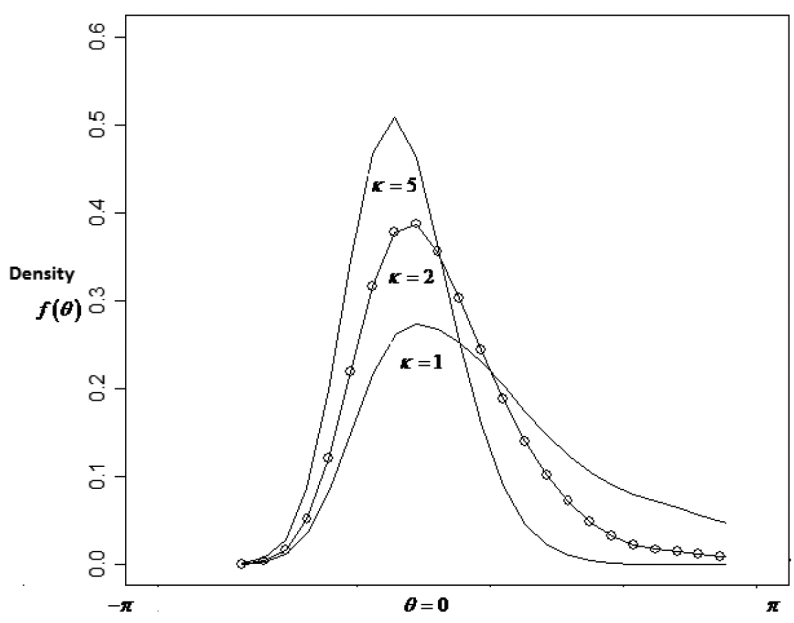

FIGURE 2. Von Mises densities for $\mu=0^{\circ}$ and different value of $\kappa$ 


$$
H_{0}: \mu_{1}=\ldots=\mu_{q}, q=2, \ldots, 10
$$

and the alternative hypothesis is that, at least one of the equalities does not hold. The likelihood ratio statistic is given by:

$$
\frac{\left(\sum_{i=1}^{q} R_{i}-R\right) /(q-1)}{\left(n-\sum_{i=1}^{q} R_{i}\right) /(n-q)} \times F_{q-1, n-q}
$$

where $R_{i}$ is the resultant length of the $i$ th sample and $R$ is the resultant length of the combined sample.

\section{LINEAR-CIRCULAR CORRELATION COEFFICIENT}

The linear-circular correlation coefficient (Mardia 1976) is used to measure the bivariate relationship between the mean direction which is circular in nature with maximum wind speed which is linear. Let $\left(x_{1}, \theta_{1}\right),\left(x_{2}, \theta_{2}\right), \ldots,\left(x_{n}, \theta_{n}\right)$ be a set of linear-circular measurements. Then, the linearcircular correlation coefficient $r$, is given by:

$$
r=\sqrt{\frac{r_{x c}^{2}+r_{x s}^{2}-2 r_{x c} r_{x s} r_{c s}}{1-r_{c s}^{2}}},
$$

where $r_{x c}=\operatorname{cor}(x, \cos \theta), r_{x s}=\operatorname{cor}(x, \sin \theta)$ and $r_{c s}=$ $\operatorname{cor}(\cos \theta, \sin \theta)$ are the sample correlation coefficients. The null hypothesis tested is that there is no relationship between variables.

\section{RESULTS AND DISCUSSION}

As mentioned earlier, the statistical model used to describe the wind pattern is the von Mises distribution. From the study carried out by Kamisan et al. (2011), the wind direction that was recorded at maximum speed for the year 2005 can be described using the von Mises distribution. In contrast to the other distribution considered namely circular uniform, wrapped-normal and wrapped-Cauchy distribution, the von Mises distribution was found to give the best fit for both of the monsoons. To further assess the suitability of the von Mises distribution plots for each station and year we obtain the goodness of fit plot based on quartiles of the observed and estimated values. We found that the points on the plots are close to a $45^{\circ}$ straight line. As an illustration, the goodness of fit plot of the wind direction data at Alor Setar in 2004 is given in Figure 3. From the plot, we may infer that the monsoon based wind direction data fits well with the von Mises distribution and is applicable for the data from 1999 to 2008 .

The first part of the result comprises of the parameter estimates of the von Mises distribution for all the locations over the ten year period (mean direction $\bar{\theta}$ and concentration parameter $\kappa)$. Also, the summary statistics of mean $(\mu)$ and standard deviation (sd) of the maximum wind speed was also given (Tables $1 \& 2$ ). Table 1 gives the summary of wind direction data and maximum wind speed over ten year period for southwest monsoon and Table 2 gives similar results for the northeast monsoon. From Tables 1 and 2, it can be seen that the mean direction of wind in Peninsular Malaysia is scattered around 3 to 4.5 radian during southwest monsoon and 0.6 to 1.2 radian during northeast monsoon. It clearly demonstrates that the prominent direction of wind that blows in west Peninsular Malaysia is from the southwest direction during southwest monsoon, and for east Peninsular Malaysia is from northeast direction during northeast monsoon. This finding can be supported by looking at the rose diagrams. From the rose diagrams in Appendix 1, for a particular station, it is worthwhile to note that the wind comes from southwest direction during southwest monsoon and from northeast direction during northeast monsoon.

As for the wind speed recorded over the ten years, from Tables 1 and 2, we can see that the standard deviation of wind speed that recorded at east Peninsular Malaysia is consistently smaller than west Peninsular Malaysia. Thus, we may say that the wind speed in east Peninsular Malaysia has smaller variation than the west Peninsular Malaysia. It is noted that the mean of wind speed is in the range of $(7.02,9.54) \mathrm{m} / \mathrm{s}$ for west Peninsular Malaysia and

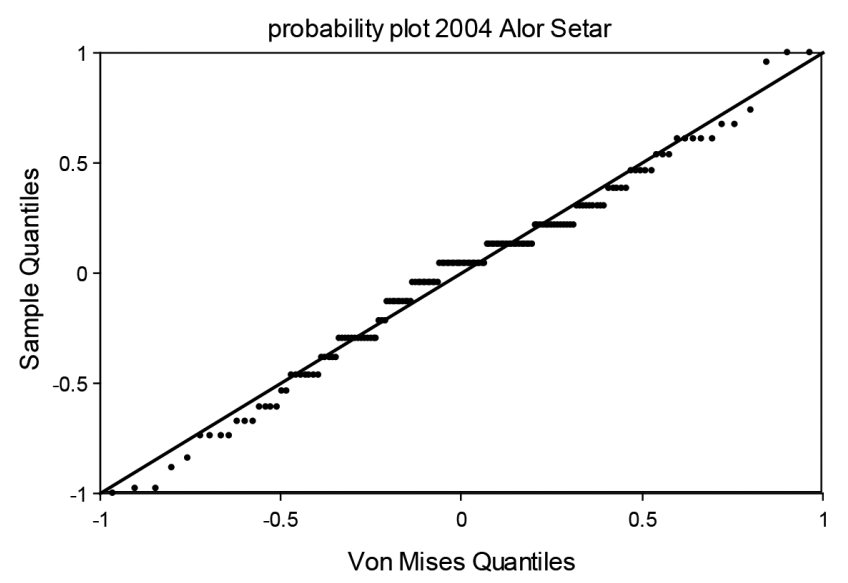

FIGURE 3. Von Mises distribution plot of wind direction data at Alor Setar in 2004 
TABLE 1. Statistical summary of wind direction data recorded at maximum wind speed at west Peninsular Malaysia from 1999 to 2008 during southwest monsoon

\begin{tabular}{|c|c|c|c|c|c|c|c|c|c|c|c|}
\hline \multirow[t]{2}{*}{ Stations } & & \multicolumn{10}{|c|}{ Year } \\
\hline & & 1999 & 2000 & 2001 & 2002 & 2003 & 2004 & 2005 & 2006 & 2007 & 2008 \\
\hline \multirow{5}{*}{$\begin{array}{l}\text { Alor } \\
\text { Setar }\end{array}$} & $\bar{\theta}$ & 4.5199 & 4.4135 & 4.4437 & 4.5444 & 4.4644 & 4.6233 & 4.5673 & 4.3788 & 4.2261 & 4.2967 \\
\hline & $\kappa$ & 2.0704 & 2.1119 & 2.1994 & 1.8434 & 1.7926 & 1.8826 & 3.1525 & 2.6556 & 2.4819 & 2.3851 \\
\hline & $\mu$ & 8.2582 & 8.1222 & 8.2196 & 8.4739 & 8.6974 & 8.8033 & 8.1464 & 8.3582 & 8.5261 & 8.7170 \\
\hline & sd & 3.0439 & 3.2253 & 3.0987 & 2.7659 & 2.4307 & 2.3940 & 2.4742 & 2.3261 & 2.8949 & 2.7848 \\
\hline & $\bar{\theta}$ & 4.0753 & 4.0056 & 4.1038 & 3.9127 & 4.0242 & 3.8461 & 4.0045 & 4.2399 & 3.9282 & 3.9549 \\
\hline \multirow{3}{*}{$\begin{array}{l}\text { Bayan } \\
\text { Lepas }\end{array}$} & $\kappa$ & 1.7296 & 1.6923 & 1.2895 & 1.6497 & 1.4509 & 1.2255 & 1.4842 & 1.4026 & 1.8773 & 2.1948 \\
\hline & $\mu$ & 9.5444 & 9.5092 & 9.5281 & 8.6719 & 8.9549 & 9.2484 & 8.5373 & 8.8183 & 8.5523 & 8.5993 \\
\hline & sd & 2.6024 & 3.0290 & 2.5279 & 2.1253 & 2.1285 & 2.4115 & 2.5178 & 2.4846 & 2.6367 & 2.4340 \\
\hline \multirow{4}{*}{ Ipoh } & $\bar{\theta}$ & 3.4322 & 3.5674 & 3.9532 & 3.942 & 3.9807 & 3.805 & 4.1467 & 4.0782 & 3.9188 & 4.0595 \\
\hline & $\kappa$ & 1.0859 & 1.1935 & 1.1604 & 1.1111 & 0.7264 & 0.8408 & 1.1866 & 0.6789 & 1.0976 & 1.0969 \\
\hline & $\mu$ & 8.9458 & 8.7693 & 8.4673 & 7.7654 & 8.1373 & 7.8379 & 8.0229 & 7.9484 & 7.6732 & 8.1771 \\
\hline & sd & 2.4840 & 2.7339 & 2.7782 & 2.3205 & 2.3296 & 2.1265 & 2.4836 & 2.2832 & 2.1898 & 2.5743 \\
\hline \multirow{4}{*}{ KLIA } & $\bar{\theta}$ & 3.6464 & 3.6345 & 3.6912 & 3.2029 & 3.2768 & 2.9674 & 3.3629 & 3.2767 & 3.1045 & 3.1033 \\
\hline & $\kappa$ & 1.117 & 1.0971 & 1.319 & 1.2138 & 1.0636 & 1.3117 & 1.1302 & 0.9411 & 0.8852 & 1.2546 \\
\hline & $\mu$ & 7.5131 & 7.9902 & 8.2222 & 7.8235 & 7.2222 & 7.4412 & 7.0248 & 7.3889 & 7.4118 & 7.1850 \\
\hline & sd & 1.6676 & 1.7928 & 2.2221 & 1.7278 & 1.8884 & 2.0048 & 1.6756 & 1.9230 & 1.8662 & 1.4520 \\
\hline \multirow{4}{*}{ Subang } & $\bar{\theta}$ & 3.9426 & 3.7147 & 3.8435 & 3.5251 & 3.8812 & 3.6971 & 3.3805 & 4.0487 & 3.691 & 3.4402 \\
\hline & $\kappa$ & 0.9735 & 1.2517 & 0.9373 & 1.1397 & 0.9765 & 0.8441 & 1.3801 & 1.3134 & 1.2753 & 1.4847 \\
\hline & $\mu$ & 9.1843 & 9.3373 & 8.8379 & 8.9621 & 8.9739 & 9.3444 & 8.5967 & 8.7078 & 8.6222 & 8.8065 \\
\hline & sd & 2.2661 & 2.3323 & 2.1628 & 2.1772 & 2.4274 & 2.3450 & 2.2332 & 1.6980 & 2.1188 & 2.1566 \\
\hline
\end{tabular}

TABLE 2. Statistical summary of wind direction data recorded at maximum wind speed at east Peninsular Malaysia from 1999 to 2008 during northeast monsoon

\begin{tabular}{|c|c|c|c|c|c|c|c|c|c|c|}
\hline \multirow[t]{2}{*}{ Stations } & & \multicolumn{9}{|c|}{ Year } \\
\hline & & $99 / 00$ & $00 / 01$ & 01/02 & $02 / 03$ & 03/04 & $04 / 05$ & 05/06 & 06/07 & 07/08 \\
\hline \multirow{5}{*}{$\begin{array}{l}\text { Kuala } \\
\text { Terengganu }\end{array}$} & $\bar{\theta}$ & 0.7403 & 0.9363 & 0.7909 & 0.7890 & 0.9724 & 0.9419 & 0.7507 & 0.9439 & 0.6900 \\
\hline & $\kappa$ & 1.9233 & 2.2077 & 3.8817 & 2.9914 & 5.0011 & 3.9060 & 2.3154 & 4.6005 & 3.5079 \\
\hline & $\mu$ & 9.4914 & 8.4046 & 8.3053 & 8.0775 & 8.0270 & 7.8536 & 7.5311 & 7.7967 & 7.6099 \\
\hline & sd & 2.6402 & 2.7533 & 3.0616 & 2.1040 & 2.0750 & 2.0370 & 2.3667 & 2.2436 & 1.9462 \\
\hline & $\bar{\theta}$ & 0.6384 & 0.6339 & 0.8349 & 0.9857 & 0.6811 & 0.7044 & 1.1377 & 1.0093 & 1.0171 \\
\hline \multirow{3}{*}{ Kuantan } & $\kappa$ & 1.7175 & 1.2414 & 1.9274 & 1.7491 & 1.8480 & 1.9310 & 1.2116 & 2.0611 & 1.7449 \\
\hline & $\mu$ & 9.4342 & 8.7252 & 9.1881 & 8.2278 & 8.1941 & 8.3245 & 7.8411 & 7.8477 & 8.0651 \\
\hline & sd & 2.6810 & 2.3594 & 1.8419 & 1.6821 & 1.7360 & 1.6271 & 1.8140 & 1.6108 & 1.6636 \\
\hline
\end{tabular}

$(7.53,9.49) \mathrm{m} / \mathrm{s}$ for east Peninsular Malaysia. However, if the distribution of mean of wind speed for both coastal area is considered, then the distribution is $(8.41,0.42)$ for west Peninsular Malaysia and $(8.27,0.34)$ for east Peninsular Malaysia. In other words, the wind speed over ten year period is less than $8.5 \mathrm{~m} / \mathrm{s}$ for both coastal areas. As mention earlier, wind speed of $8.5-10.99 \mathrm{~m} / \mathrm{s}$ has good potential for energy resource (Razali 2010). Thus it can be inferred that wind has a small potential in providing an alternative source of energy.

\section{WATSON-WILLIAM TEST FOR WIND DIRECTION DATA}

In order to check if there is any significant change of the mean direction over the ten year period, the Watson-
William Test is performed and the results are shown in Table 3 . The $p$-value given for each test is the probability associated with the null hypothesis that the mean angles are equal. If the mean angles are equal, then there is no change in the mean direction of wind for ten years.

From Table 3 it can be seen that for the southwest monsoon there is statistical evidence with significance level 0.05 , that there is a change in the direction of wind over the ten year period for all stations with the exception of Bayan Lepas. Similar conclusions can be made for the northeast monsoon where both stations recorded significant difference in the wind direction. Also, from Table 1, it can be seen that for Bayan Lepas station, the difference between the minimum (2004) and maximum (2006) mean direction of wind calculated over ten year period is very 
TABLE 3. Watson-William Test for mean direction of wind in Peninsular Malaysia from 1999 to 2008 during southwest monsoon and northeast monsoon

\begin{tabular}{lccccc|cc}
\hline Monsoon & \multicolumn{5}{c|}{ Southwest Monsoon } & \multicolumn{2}{c}{ Northeast Monsoon } \\
\hline Stations & Alor Setar & Bayan Lepas & Ipoh & KLIA & Subang & Kuala Terengganu & Kuantan \\
$p$-value & 0.000 & 0.066 & 0.000 & 0.000 & 0.000 & 0.000 & 0.000 \\
\hline
\end{tabular}

small, indicating that there is no change in the direction of wind. Other station such as Kuala Terengganu has large difference between the minimum (07/08) and maximum $(03 / 04)$ mean direction of wind.

These results are similar with the rose diagrams where it is note that although the wind predominantly came from a certain direction during particular monsoon, there is a gradual change in the direction of wind over the ten year period. For illustration, rose diagrams for selected years for the Alor Setar Station show that the mean has shifted from about $270^{\circ}$ to the third quadrant of the circle. Similar conclusions can be made for the northeast monsoon in which rose diagrams for selected years for Kuala Terengganu Stations are given in Appendix 1.

\section{ANALYSIS ON CONCENTRATION PARAMETER OF WIND DIRECTION DATA}

The estimates of the concentration parameter or dispersion of wind direction for ten years are also given in Tables 1 and 2. In general terms, it can be seen that the concentration parameter value for northeast monsoon is slightly higher than southwest monsoon. Even though there is a change in mean direction in the past ten years, the direction of wind that was recorded during northeast monsoon is less scattered or less dispersed than during southwest monsoon. Therefore, the direction of wind during that time is more prominent compared to southwest monsoon. Looking at the stations, the concentration parameters recorded at Alor Setar are consistently higher than other stations during southwest monsoon. Similarly, Kuala Terengganu gives consistently higher concentration parameter during northeast monsoon compared to other stations. It is worthwhile to note that, Ipoh has the lowest concentration parameter during southwest monsoon suggesting that the wind direction in this station is not prominent.

These finding are consistent when we consider the rose diagrams. It can be seen that wind directions for all stations in east Peninsular Malaysia are close to each other as compared to the stations in west Peninsular Malaysia. These results give strong indication that the direction of wind in east Peninsular Malaysia is more stable than the west Peninsular Malaysia. These findings may be use in harnessing potential future of wind energy in Malaysia and provide some insights into the climatic change in Peninsular Malaysia. For example, floods due to heavy rainfall occurred every year during northeast monsoon season. A haze crisis has also occurred in the central part of Peninsular Malaysia (the worst since 1997) in August 2005 during southwest monsoon. Coincidently, high concentration parameters are recorded at most stations during that period of time. Perhaps, the high concentration parameters observed over the ten year period may, in some way, contribute towards the climate change in the Peninsular.

\section{CORRELATION OF WIND DIRECTION AND WIND SPEED}

Tables 4 and 5 show the correlation values between the wind direction and wind speed in Peninsular Malaysia for seven locations. The $p$-value given for each test is the probability associated with the null hypothesis that there is no relationship between wind direction and wind speed. From Table $4, p$-values less than 0.05 indicating a significant correlation can be seen in most stations, over the period of ten years. Some abnormalities can be seen in some stations such as Alor Setar (1999, 2000 and 2008), Ipoh (2004, 2005 and 2007), Bayan Lepas (2004 and 2005) and KLIA in 2007. Therefore at 0.05 significance level, we may say that there is a significant relationship between wind direction and wind speed at west Peninsular Malaysia during southwest monsoon. To quantify the strength of linear-circular correlation, coefficient values are computed and are found to be in the range of 0.15 to 0.35 , thus suggesting that the circular-linear relationship is not strong.

For the northeast monsoon as given in Table 5, the relationship between wind direction and wind speed is somewhat significant for Kuala Terengganu for the years after 2005 and for Kuantan, the relationship dates back to as early as the year 2000 . The correlation coefficients are generally less than 0.4 , thus it can be concluded that the correlation between wind direction and wind speed is somewhat weak. These results are not surprising since from Tables 1 and 2 it can be seen that even though the mean direction of wind or its concentration parameter is high, the mean of wind speed is low. Hence, we may suggest that the direction of wind does not influence the speed of wind in Peninsular Malaysia regardless from where it blows.

\section{CONCLUSION}

From this study, it can be concluded that there are significant changes in the direction of wind and high concentration parameters for the period of ten years in Peninsular Malaysia. This behavior may be due to the gradual climate change observed worldwide. The direction of wind observed during the northeast monsoon is less scattered than during the southwest monsoon. This means 
TABLE 4. Correlation result between the wind direction and wind speed at west Peninsular Malaysia from 1999 to 2008 during southwest monsoon

\begin{tabular}{ccccccc}
\hline Year & Stations & Alor Setar & Bayan Lepas & Ipoh & KLIA & Subang \\
\hline \multirow{2}{*}{1999} & $r$ & 0.106 & 0.338 & 0.241 & 0.325 & 0.237 \\
& $p$-value & 0.187 & 0.000 & 0.000 & 0.000 & 0.000 \\
2000 & $r$ & 0.094 & 0.346 & 0.218 & 0.172 & 0.237 \\
& $p$-value & 0.268 & 0.000 & 0.000 & 0.012 & 0.000 \\
2001 & $r$ & 0.241 & 0.173 & 0.176 & 0.228 & 0.227 \\
& $p$-value & 0.000 & 0.011 & 0.01 & 0.000 & 0.000 \\
2002 & $r$ & 0.153 & 0.167 & 0.173 & 0.389 & 0.245 \\
& $p$-value & 0.029 & 0.015 & 0.011 & 0.000 & 0.000 \\
2003 & $r$ & 0.235 & 0.182 & 0.227 & 0.188 & 0.107 \\
& $p$-value & 0.000 & 0.007 & 0.000 & 0.005 & 0.18 \\
\multirow{2}{*}{2004} & $r$ & 0.292 & 0.053 & 0.095 & 0.218 & 0.213 \\
& $p$-value & 0.000 & 0.661 & 0.257 & 0.000 & 0.001 \\
\multirow{2}{*}{2006} & $r$ & 0.267 & 0.027 & 0.022 & 0.333 & 0.203 \\
& $p$-value & 0.000 & 0.898 & 0.93 & 0.000 & 0.002 \\
2007 & $r$ & 0.256 & 0.151 & 0.281 & 0.065 & 0.219 \\
& $p$-value & 0.000 & 0.033 & 0.000 & 0.53 & 0.000 \\
& $r$ & 0.045 & 0.22 & 0.049 & 0.386 & 0.205 \\
& $p$-value & 0.735 & 0.000 & 0.7 & 0.000 & 0.002 \\
& $p$-value & 0.086 & 0.163 & 0.236 & 0.17 & 0.264 \\
& & 0.328 & 0.019 & 0.000 & 0.013 & 0.000 \\
\hline
\end{tabular}

TABLE 5. Correlation result between the wind direction and wind speed at east Peninsular Malaysia from 1999 to 2008 during northeast monsoon

\begin{tabular}{|c|c|c|c|c|c|c|c|c|c|c|}
\hline \multirow[t]{2}{*}{ Station } & & \multicolumn{9}{|c|}{ Year } \\
\hline & & $99 / 00$ & $00 / 01$ & $01 / 02$ & $02 / 03$ & 03/04 & $04 / 05$ & 05/06 & 06/07 & 07/08 \\
\hline Kuala & $r$ & 0.062 & 0.108 & 0.06 & 0.056 & 0.085 & 0.043 & 0.229 & 0.158 & 0.133 \\
\hline Terengganu & $p$-value & 0.563 & 0.178 & 0.584 & 0.627 & 0.341 & 0.757 & 0.000 & 0.025 & 0.07 \\
\hline \multirow{2}{*}{ Kuantan } & $r$ & 0.061 & 0.23 & 0.262 & 0.296 & 0.357 & 0.167 & 0.261 & 0.228 & 0.146 \\
\hline & $p$-value & 0.571 & 0.000 & 0.000 & 0.000 & 0.000 & 0.016 & 0.000 & 0.000 & 0.041 \\
\hline
\end{tabular}

the direction of wind during northeast monsoon is more prominent as compared to the southwest monsoon.

In search of environmentally friendly source of energy, the potential wind energy source is often studied. From the hourly data obtained at an altitude $18 \mathrm{~m}$ from 2005 to 2006 in Mengabang Telipot Kuala Terengganu, a location in the east coast Peninsular Malaysia, Zaharim et al. (2009) noted that future potential wind energy source in Malaysia is based on its location and suitable wind speed. Masseran et al. (2012b) suggested that the wind speed at Peninsular Malaysia were persistent but averagely low and identified Mersing in southeast region of Peninsular Malaysia as the most potential location for energy production based on the analysis of hourly wind speed data recorded at ten stations from 1 January 2007 to 30 November 2009.

Recently, Tiang and Ishak (2012) studied wind speed data recorded from January to December 2008 and concluded that the measurement site at Bayan Lepas in northwest region of Peninsular Malaysia has a limited wind potential. In this study, based on the ten-year period of maximum wind speed, the findings suggested that wind may not be a viable alternative source in harnessing energy. Chiang et al. (2003) however, suggested that the winds in the east coast of Peninsular Malaysia can be considered as the future potential wind energy source in Malaysia based on monthly wind waves, swells and wind characteristics taken for the period of 16 years from 1985 to 2000 .

It is also found that there is little or no relationship between wind speed and direction. It is worthwhile to note that similar finding was also discovered by Jammaladaka and Lund (2006) when they measured the correlation between wind direction and wind speed in Texas on 2005. In this study, although there is evidence of the bivariate correlation between the wind speed and wind direction, the small coefficients values suggest that circular-linear relationship are somewhat weak. This indicates that the direction of wind does not influence the speed of wind in Peninsular Malaysia regardless from where it blows and vice versa. In conclusion, findings from this study may provide useful information in giving a better understanding 
of the behavior of the wind, its potentiality as an alternative energy source and predicting the future climatic changes in Malaysia.

\section{ACKNOWLEDGEMENTS}

The authors wish to thank University of Malaya (RG 23912AFR) for the research grant in undertaking this research.

\section{REFERENCES}

Amos, D.E. 1974. Computation of modified Bessel functions and their ratios. Mathematics of Computation 28(125): 239-251.

Batschelet, E. 1981. Circular Statistics in Biology. London: Academic Press.

Bernama. 2012. Haze Drifting in from Riau. http://blis2.bernama. $\mathrm{com} /$ get Article.. o $? \mathrm{id}=48458 \& \mathrm{tid}=99 \& \mathrm{cid}=2$. Accessed on 3 January 2012.

Bernama. 2008. Banjir 3 Negeri Makin Buruk. http://blis2. bernama.com/ getArticle.do?id=106665 \&tid=79\&cid=3. Accessed 8 January 2012.

Bernama. 1998. Kesan El-Nino. http://blis2.bernama.com/ getArticle.do? id $=236293 \&$ tid $=41 \&$ cid $=3$. Accessed on 3 January 2012.

Best, D.J. \& Fisher, N.I. 1981. The bias of the maximum likelihood estimators of the von Mises-Fisher concentration parameters. Communication in Statistics - Simulation and Computation 10(5): 493-502.

Bowers J.A., Morton I.D. \& Mould G.I. 2000. Directional statistics of the wind and waves. Applied Ocean Research 22: $13-30$.

Brunsdon C. \& Charlton M. 2006. Local trend statistics for directional data - a moving window approach. Computers, Environment and Urban Systems 30: 130-142.

Chiang, E.P., Zainal, Z.A., Aswatha Narayana, P.A. \& Seetharamu, K.N. 2003. Potential of renewable wave and offshore wind energy sources in Malaysia. Marine Technology 2003 Seminar.

Dobson, A.J. 1978. Simple approximations for the von mises concentration statistic. Journal of the Royal Statistical Society, Series C (Applied Statistics) 27(3): 345-347.

Fredolin T. Tangang, Liew Juneng, Ester Salimun, Kwan Meng Sei, Loh Jui Le \& Halimatun Muhamad 2012. Climate change and variability over Malaysia: Gaps in science and research information. Sains Malaysiana 41(11): 1355-1366.

Gumbel, E.J., Greenwood, J.A. \& Durand, D. 1953. The circular normal distribution: Theory and tables. Journal of American Statistical Association 48(261): 131-152.

Hassan, S.F., Hussin, A.G. \& Zubairi, Y.Z. 2012. Improved efficient approximation of concentration parameter and confidence interval for circular distribution. ScienceAsia 38(1): 118-124.

Islam, M.R., Saidur, R. \& Rahim, N.A. 2011. Assessment of wind energy potentiality at Kudat and Labuan, Malaysia using Weibull distribution function. Energy 36(2): 985-992.

Jammalamadaka, S.R. \& Lund, U.J. 2006. The effect of wind direction on ozone levels: A case study. Environ. Ecol. Stat. 13: 287-298.

Jammalamadaka, S.R. \& SenGupta, A. 2001. Topics in Circular Statistics. Singapore: World Scientific Publishing Co. Pte. Ltd.

Kamisan, N.A.B., Hussin, A.G. \& Zubairi, Y.Z. 2010. Finding the best circular distribution for southwesterly monsoon wind direction in Malaysia. Sains Malaysiana 39(3): 387-393.
Kamisan, N.A.B., Hussin, A.G. \& Zubairi, Y.Z. \& Hassan, S.F. 2011. Distribution of wind direction recorded at maximum wind speed: A case study of Malaysian wind data for 2005 . International Journal of the Physical Sciences 6(7): 18401850.

Mahmud, M. \& Ab Liah, I.H. 2010. Pencemaran udara di Bukit Rambai, Melaka sewaktu peristiwa jerebu tahun 2005. Geografia Online Malaysian Journal of society and Space 6(3): 30-39.

Malaysian Meteorological Department. 2009. Climate Change Scenarios for Malaysia 2001-2099. Ministry of Science, Technology and Innovation Malaysia.

Mardia K.V. 1976. Linear-circular correlation coefficients and rhythmomentry. Biometrika 63: 403-405.

Mardia, K.V. 1972. Statistics of Directional Data. New York: Academic Press.

Mardia, K.V. \& Jupp, P.E. 2000. Directional Statistics. England: John Wiley \& Sons Ltd.

Mardia, K.V.\& Zemroch, P.J. 1975a. Algorithm AS 80: Spherical statistics. Journal of the Royal Statistical Society, Series C (Applied Statistics) 24(1): 144-146.

Mardia, K.V.\& Zemroch, P.J. 1975b. Algorithm AS 81: Circular statistics. Journal of the Royal Statistical Society, Series C (Applied Statistics) 24(1): 147-150.

Masseran, N., Razali, A.M. \& Ibrahim, K. 2012a. An analysis of wind power density derived from several wind speed density functions: The regional assessment on wind power in Malaysia. Renewable and Sustainable Energy Reviews 16: 6476-6487.

Masseran, N., Razali, A.M., Ibrahim, K. \& Wan Zin, W.Z. 2012b. Evaluating the wind speed persistence for several wind stations in Peninsular Malaysia. Energy 37: 649-656.

Muhammad Barzani Gasim, Salmijah Surif, Mazlin Mokhtar, Mohd. Ekhwan Hj. Toriman, Sahibin Abd. Rahim \& Chong Huei Bee. 2010. Flood analysis of December 2006: Focus at Segamat Town Johor. Sains Malaysiana 39(3): 353-361.

Razali, A.M., Sapuan, M.S., Ibrahim, K., Zaharim, A. \& Sopian, K. 2010. Mapping of annual extreme wind speed analysis from 12 stations in Peninsular Malaysia. Selected Topics in System Science and Simulation in Engineering. 9th WSEAS International Conference on System Science and Simulation in Engineering (ICOSSSE '10). Iwate Prefectural University, Japan. October 4-6. pp. 397-403.

Nur Aishah Sulaiman, Faizah Husain, Khairil Afendy Hashim \& Abd. Manan Samad. 2012. A study on flood risk assessment for Bandar Segamat sustainability using remote sensing and GIS approach. 2012 IEEE Control and system Graduate Research Colloquium (1CSGRC 2012). Shah Alam, Selangor, Malaysia. July 16-17. pp. 386-391.

The Star. 2005. Sudden Haze Hits Klang Valley. http://thestar. com.my/news/story.asp?file $=/ 2005 / 8 / 3 /$ nation $/ 11661487 \&$ $\mathrm{sec}=$ nation. Accessed on 8 January 2012.

The Star.2006.Typhoon Utor to Blame.http://thestar.com.my/news/ story.asp?file $=2006 / 12 / 21 /$ nation $/ / 16380186 \&$ sec $=$ nation . Accessed on 3 January 2012.

Tiang, T.L. \& Ishak, D. 2012. Technical review of wind energy potential as small-scale power generation sources in Penang Island Malaysia. Renewable and Sustainable Energy Reviews 16: 3034-3042.

Zaharim, S.K., Najid, A., Razali, M. \& Sopian, K. 2009. Wind speed analysis in the east coast of Malaysia. European Journal of Scientific Research 32(2): 208-215. 
S.Z. Satari*

Institute of Graduate Studies, University of Malaya 50603 Kuala Lumpur, Wilayah Persekutuan Malaysia

\section{S.Z. Satari*}

Faculty of Industrial Sciences \& Technology

Universiti Malaysia Pahang

Lebuhraya Tun Razak 26300 Gambang, Kuantan,

Pahang Darul Maklmur

Malaysia

Y.Z. Zubairi \& S.F. Hassan

Centre for Foundation Studies in Sciences

University of Malaya

50603 Kuala Lumpur,

Wilayah Persekutuan Malaysia
A.G. Hussin

Faculty of Defence Sciences and Technology,

National Defence University of Malaysia, Kem Sungai Besi

57000 Kuala Lumpur, Wilayah Persekutuan

Malaysia

*Corresponding author; email: zanariah@ump.edu.my

Received: 25 July 2013

Accepted: 30 June 2015 

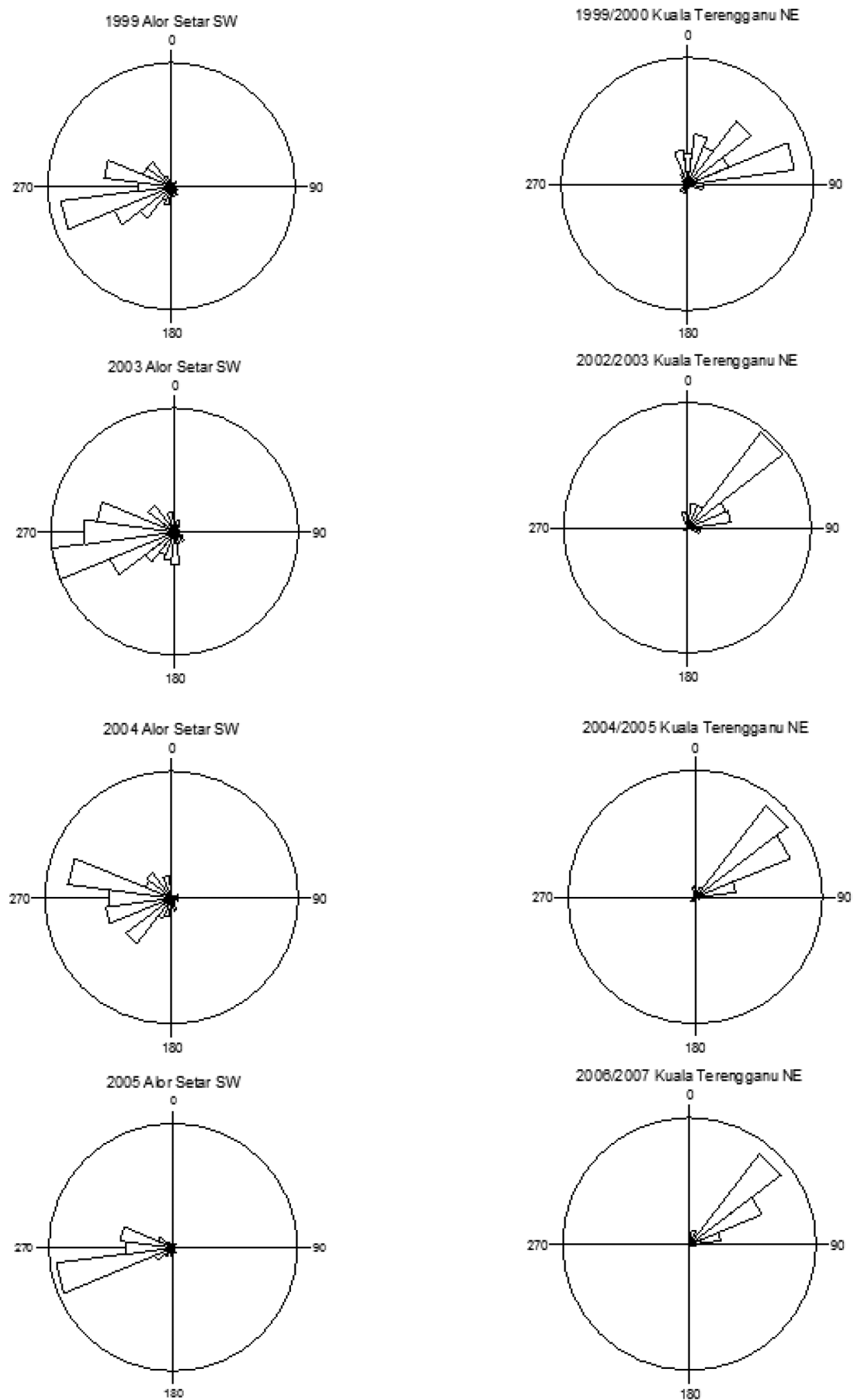